\title{
Relationship between Socio-Economic Aspects and Education Level of Group Ages 18-25 towards Teeth-Brushing Habit
}

\author{
Indriasari Putri Rahmadhany ${ }^{1}$, Aulia Ramadhani ${ }^{2,3}$, Abigail Reyhan Kesuma ${ }^{1}$, \\ Riska Nur Arifianti P.N. ${ }^{1}$, Nada Fajrina ${ }^{1}$, Nadhia S. Latuamury ${ }^{1}$ \\ ${ }^{1}$ Undergraduate Student, Faculty of Dental Medicine, Universitas Airlangga, ${ }^{2}$ Graduate Student of Health \\ Administration and Policy, Faculty of Public Health, Universitas Airlangga, ${ }^{3}$ Department of Dental Public Health, \\ Faculty of Dental Medicine, Universitas Airlangga
}

\begin{abstract}
Background: Dental and oral health problems in the community can arise due to behavioral factors or attitudes ignoring oral and dental hygiene. The level of education and the factors that affect children's own dental health have been presented in various studies.
\end{abstract}

Objective: To analyze the relationship between socio-economic aspects and the level of education of people aged 18-25 years towards the habit of brushing teeth in the city of Surabaya.

Method: This type of research is an observational analytic study with a design using a cross sectional study approach. In this study, related data were collected regarding the relationship between education and socioeconomic levels of the age range of 18-25 years on the habit of brushing properly taken at the same time.

Results: There was no significant relationship between education and socio-economic level with the habit of brushing teeth.

Conclusion: It was concluded that there was no significant relationship between education level with the habit of brushing teeth and the relationship of socioeconomic level with the habit of brushing teeth.

Keywords: Education, Socio-economy, teeth-brushing habit.

\section{Introduction}

Oral health is important for general health and quality of life. A healthy mouth condition is free from throat cancer, mouth infections and wounds, gum disease, tooth decay, tooth loss, and other illnesses,

\section{Corresponding Author:}

Aulia Ramadhani

Graduate Student of Health Administration and Policy, Faculty of Public Health, Universitas Airlangga and Department of Dental Public Health, Faculty of Dental Medicine, Universitas Airlangga; Prof. Dr. Moestopo Street No. 47

Phone Numbers: (+6231) 5030255, 5020256

Facsimile Numbers: (+6231)5020256;

e-mail: ramadhani.rara94@gmail.com which can cause limiting disorders in biting, chewing, smiling, talking, and psychosocial well-being ${ }^{1}$. Dental health is part of oral health, which is important. Dental caries is one of the dental health disorders. Dental caries are formed due to the presence of food scraps attached to the teeth, which then causes a decrease in tooth mineral. As a result, teeth become porous, hollow, even broken. Dental caries causes a decrease in the chewing power and disruption of digestion, which indirectly results in a child's growth is less than optimal'.

Behavior Maintaining health Oral cavity, one of which is done by regularly brushing teeth and choosing the right toothbrush. Brushing teeth is the most important thing to maintain oral health. Brushing teeth must be accustomed since childhood ${ }^{3}$. The recommended method for brushing teeth is the bass method, which is by tilting the toothbrush 45 degrees brushed from the 
direction the tooth root touches the edge of the gum. The toothbrush is moved back and forth within 15 seconds. In the posterior teeth, the tooth surface is brushed in the vertical direction ${ }^{3}$. In addition to paying attention to how to brush your teeth, the selection of toothbrushes and toothpaste must also be considered. The shape of the toothbrush must have a surface of the bristles having a length of 2.5-3 mm and a width of 8-9.5 $\mathrm{mm}$ and the brush bristles evenly cut. After each use, the toothbrush must be washed with water so that no food remains are left behind. Toothbrushes must also be replaced 2-3 months ${ }^{4}$.

Oral hygiene has been applied since ancient times, but brushing teeth is only done in modern times. Nowadays, various oral care products have been introduced to the public. This shows how important it is to maintain oral health ${ }^{5}$. Brushing teeth has the effect of removing dental plaque in varying degrees according to the characteristics of the duration of toothbrushes and brushing. Brushing teeth can also alleviate certain oral diseases, such as periodontitis and caries, which are considered to be a public health problem ${ }^{6}$.

Knowledge, attitudes, and actions of the mother will determine the dental and oral health status of children later. Parents must know how to care for their children's teeth and must be able to teach their children how to maintain good dental health ${ }^{7}$. Many parents still assume that baby teeth are only temporary and will be replaced by permanent teeth. So parents often assume that damage to baby teeth caused by poor oral hygiene is not a problem ${ }^{8}$.

Based on data from the Indonesia Basic Health Survey 2018, it states that the proportion of dental and mouth problems is $57.6 \%$ and only $10.2 \%$ receive services from dental medical personnel ${ }^{9}$. The percentage of people who have the right brushing behavior is only
$2.8 \%$. Dental health problems that commonly occur in Indonesia is dental caries. The treatment needed to solve these dental health problems requires high costs. Therefore, it is necessary to prevent prophylaxis against diseases of the teeth, one of which is to brush teeth properly regularly ${ }^{10}$. Dental and oral health problems in the community can arise due to behavioral factors or attitudes ignoring dental and oral hygiene ${ }^{11,12}$. There is a relationship between the level of educational background with one's knowledge of how to brush teeth properly ${ }^{11}$. The level of education and the factors that affect children's dental health have been presented in various studies ${ }^{13}$. On the other hand, similar studies have not been done in adults. With this phenomenon, the researcher aims to conduct research to determine the relationship between social economic aspects and the level of public education on knowledge about how to brush teeth properly. And to predict the relationship, researchers used sample data from Surabaya residents.

\section{Method}

This study was a cross-sectional observational analytic study with a research instrument in the form of a questionnaire. The sample used was 118 related to good tooth brushing habits. Analysis of the data used in this study is Bivariant Correlation with the Spearman Correlation test.Score details: 8-10: Good, 6-7: Well, and $<6$ : Poor

\section{Results}

Table 1: Teeth-brushing habit

\begin{tabular}{|c|l|c|c|}
\hline No. & Status & Number of Respondents & Percentage \\
\hline 1. & Good & 104 & $88,1 \%$ \\
\hline 2. & Well & 14 & $11,9 \%$ \\
\hline 3. & Poor & 0 & $0 \%$ \\
\hline
\end{tabular}

Table 2: Characteristics of Respondents and analysis of the relationship between educational level and social aspects with the habit of brushing teeth

\begin{tabular}{|l|c|c|c|c|}
\hline Variable & $\mathbf{n}$ & Percentage & P-Value & Correlation Coefficient \\
\hline Educational Background & & & & \\
Elementary School & 0 & $0 \%$ & & \\
Junior High School & 0 & $0 \%$ & 0,296 & -0.097 \\
Senior High School & 91 & $77,1 \%$ & & \\
Bachelor & 27 & $22,9 \%$ & & \\
\hline Socio-economy aspect & & & & \\
Low & 93 & $78,8 \%$ & & 0.027 \\
Moderate & 15 & $12,7 \%$ & 0,768 & \\
High & 10 & $8,5 \%$ & & \\
\hline
\end{tabular}


Based on the characteristics of "Educational background" shown in table 2 , it can be seen that the respondents with the last elementary and junior high school education are 0 people with a percentage of $0 \%$. Respondents with the most recent high school education were 91 people with a percentage of $77.1 \%$, and respondents with the most recent Bachelor/diploma education were 27 people with a percentage of $22.9 \%$.

Based on socio-economic characteristics based on the average salary received by respondents in table 2 , it appears that respondents with low socio-economic status are 93 people with a percentage of $78.8 \%$, respondents with Medium socio-economic status are 15 people with a percentage of $12,7 \%$, and respondents with high socioeconomic status as many as 10 people with a percentage of $8.5 \%$.

Based on the table above, it can be concluded that there is no significant relationship between the level of education and the habit of brushing because Sig. 0.296 , where the value is more than 0.05 . Similarly, the relationship between the socioeconomic level and the habit of brushing teeth has a Sig value of 0.769 .

\section{Discussion}

This research was carried out around the area of Universitas Airlangga, Surabaya, East Java. This research was conducted by the method of distributing online questionnaires through social media platforms. The results of the questionnaire as many as 118 respondents were dominated by adolescents with educational background at the high school level.

The results of this study indicate that there is no significant relationship between the level of education and socio-economics with the habit of brushing teeth in people aged 18-25 years in Surabaya. These results were obtained from the analysis of the data we did using a questionnaire distributed to random samples in the Surabaya area. The results showed that $88.1 \%$ of adolescents aged 18-25 years in the Surabaya area answered the questionnaire well. The insignificant result was due to the possibility that most of the samples were taken from adolescents living in urban areas especially in the East Java area of Surabaya, with most of their socioeconomic status and high level of education and anything easily accessible.

This study shows that the high socioeconomic figures in urban areas are far higher when compared to remote areas. The higher the socioeconomic level of the community, the higher the level of education of the community, conversely if the socioeconomic level of the community is low, the lower the level of education taken $^{14}$. Therefore, it can also be concluded that the level of education in urban areas has begun to be evenly distributed so that an increase in the level of socioeconomics and with the presence of such education the level of knowledge is also increasing ${ }^{15}$. Public awareness will also maintain oral hygiene by brushing teeth properly and has been implemented well.

\section{Conclusion}

Based on research conducted with 118 samples ranging in age from 18-25 years in the area around Campus A, B, and C of Universitas Airlangga, Surabaya, it was concluded that there was no significant relationship between education level with toothbrushing habits as well as the relationship between socioeconomic levels and habits brushing teeth.

Conflicts of Interest: There are no conflicts of interest.

Source of Funding: Self-Funding

Ethical Clearance: Approved

\section{References}

1. WHO. Oral health [Internet]. WHO. 2019 [cited 2020 Oct 15]. Available from: https://www.who. int/news-room/fact-sheets/detail/oral-health

2. Sinaga A. Faktor-faktor yang Berhubungan dengan perilaku Ibu dalam Mencegah Karies Gigi Anak Usia 1-5 Tahun di Puskesmas Babakan Sari Bandung. J Darma Agung. 2013;XXI:1-10.

3. Ministry of Health of the Republic of Indonesia. Pentingnya Pemeriksaan Gigi Dan Mulut 6 Bulan Sekali. Jakarta: Kementrian Kesehatan RI; 2016.

4. Sihite, Jesica N. Hubungan Perilaku Pemeliharaan Kesehatan Gigi dan Mulut dengan Pengalaman Karies dan Oral Indeks Higiene pada murid SMP. Universitas Sumatera Utara.; 2011.

5. Jardim J, Alves L, Maltz M. The history and global market of oral home-care products. Braz Oral Res. 2009;23:17-22.

6. Koerber A, Burns JL, Berbaum M, Punwani I, Levy $\mathrm{SR}$, Cowell J, et al. Toothbrushing patterns over time in at-risk metropolitan African-American 5 th- 8 th 
graders. J Public Health Dent [Internet]. 2005 Sep [cited 2020 Oct 15];65(4):240-3. Available from: http://dentistry.uic.edu/depts/pedd/faculty.htm

7. Park J-B, Han K, Park Y, Ko Y. Association between socioeconomic status and oral health behaviors: The 2008-2010 Korea national health and nutrition examination survey. Exp Ther Med. 2016;12:2657-64.

8. Piwitaning. Hubungan Pengetahuan, Sikap dan Tindakan Ibu Dalam Pemeliharaan Kesehatan Gigi Dan Mulut Dengan Status Kesehatan Gigi Anak Balita Usia 3-5 th (Studi di Desa Pohjejer Kecamatan Gondang, Kabupaten Mojokerto). Universitas Airlangga; 2013.

9. Ministry of Health of the Republic of Indonesia. Riset Kesehatan Dasar Tahun 2018. Jakarta; 2018.

10. Smyth E, Caamaño F. Factors related to dental health in 12-year-old children: a cross-sectional study in pupils. Gac Sanit. 2005;19(2):113-9.

11. Kawuryan U. Hubungan pengethauan tentang kebersihan gigi dan mulut dengan kejadian karies anak SDN Kleco II kelas V dan VI Laweyan
Surakarta. Universitas Muhammadiyah Surakarta; 2008.

12. Fankari. Pengaruh Penyuluhan Dengan Metode Stimulasi dan Demonstrasi Terhadap Perubahan Perilaku Menjaga Kesehatan Gigi Dan Mulut Anak Sekolah Dasar. Universitas Gajah Mada; 2004.

13. Tashiro Y, Nakamura K, Seino K, Ochi S, Ishii $\mathrm{H}$, Hasegawa $\mathrm{M}$, et al. The impact of a schoolbased tooth-brushing program on dental caries: a cross-sectional study. Environ Health Prev Med [Internet]. 2019 [cited 2020 Nov 10];24(83):1-9. Available from: https://doi.org/10.1186/s12199019-0832-6

14. Basrowi, Juariyah S. Analisis Kondisi Sosial Ekonomi Dan Tingkat Pendidikan Masyarakat Desa Srigading, Kecamatan Labuhan Maringgai, Kabupaten Lampung Timur. J Ekon Pendidik. 2010;7(1).

15. Slot D, Wiggelinkhuizen L, Rosema N, Van der Weijden G. The efficacy of manual toothbrushes following a brushing exercise: a systematic review. Int J Dent Hyg. 2012;10(3):187-97. 